\title{
Archaeologia
}

http://journals.cambridge.org/ACH

Additional services for Archaeologia:

Email alerts: Click here

Subscriptions: Click here

Commercial reprints: Click here

Terms of use : $\underline{\text { Click here }}$

\section{XII.-On Archaic conceptions of property in relation to the Laws of Succession; and their survival in England}

G. Laurence Gomme

Archaeologia / Volume 50 / Issue 01 / January 1887, pp 195 - 214

DOI: 10.1017/S0261340900005609, Published online: 25 January 2012

Link to this article: http://journals.cambridge.org/abstract S0261340900005609

How to cite this article:

G. Laurence Gomme (1887). XII.-On Archaic conceptions of property in relation to the Laws of Succession; and their survival in England. Archaeologia, 50, pp 195-214 doi:10.1017/S0261340900005609

Request Permissions : $\underline{\text { Click here }}$ 
XII.-On Archaic conceptions of property in relation to the Laws of Succession; and their survival in England. By G. Laurence Gonue, F.S.A.

Read February 18, 1886.

Primogeniture, aided by legal powers and by the strong necessities of feudal polity, has become in this country the dominant form of succession to title and estate, and has consequently thrust out of consideration many other forms which exist here and there. Two of these other forms, Gavelkind and borough-English (so called), have received some attention from lawyers and legal antiquaries, and they obtain in many localities as the legal form of succession; but there are other customs which have been altogether neglected, and which obtain in only a few isolated localities. The lawyer at the bidding of statesmen has striven for the furtherance of the right of primogeniture, and every other custom has had to prove its case before it could obtain recognition. Therefore, in a certain sense the law has never recognised any other form of succession than primogeniture. But what I shall have to point out in the following pages is that in the annals of rural England there are many conceptions attached to the holding of property, which, though succumbing in law to primogeniture, have left a history behind which is well worth examining. Before Mr. Elton dealt with primogeniture and juniorright as common descendants from one parent, an examination of the right of primogeniture never led the inquirer beyond the area bounded by feudal history. But by examining the two forms of succession together it has been shown that we arrive at the archaic family. But even this is not enough. The very first question which comparative science has to ask, is-why should we seek to ascertain the origin of the laws of succession by an exclusive study of two forms only? It is necessary to base one's inquiry not upon an examination of some $2 \mathrm{c} 2$ 
special forms, however widely prevalent, to the exclusion of all others, however narrowly limited; but upon an examination of all the forms of succession which have survived the exigencies of successive waves of political requirements. The process is somewhat tedious, perhaps, and somewhat speculative, but at almost every stage we are assisted by the important comparison which Hindu law and custom presents. In India the forms of succession have passed through varying stages of development, and fortunately under the eyes of English lawyers and students of archaic customs, and thus we have a compact body of evidence of the utmost value. It is only by such aids as comparative history can afford us that we may hope to fathom the darkness of our own early legal history, for, as Sir Francis Palgrave long ago remarked, "we have not a single law, and hardly a single document from which the course of the descent of land can be inferred." a Something has been recovered since Palgrave's time, it is true; but it has been recovered by the light thrown upon old documents by living archaic custom elsewhere. It seems worth while, therefore, to turn once again to the subject of succession, and endeavour to ascertain whether archaic polity, as made known to us by Hindu and other primitive customs, cannot account for some of the peculiar customs known to obtain in Great Britain, and find out their place of relationship to the well-known forms of primogeniture and junior-right.

Now the modern laws of succession appertain to property passing from an individual owner to his individual successor; and the first question we must ask ourselves, is-what is the original relationship of individuals to property? To put it broadly, it might be said that the progress towards civilization has been a progress towards the recognition of individual rights and individual status. Mr. Spencer has said, and there is much evidence to support his statement, that the savage lacks the extended consciousness of individual possession, and under his conditions it is impossible for him to have it. Beyond the few rude appliances ministering to his bodily wants, the primitive man has nothing that he can accumulate-there is no sphere for an acquisitive tendency. ${ }^{b}$ This is at the very beginning of things, but its principle lasts down to the dawn of civilized history. Thus when we come to the primitive group, forming an integral portion of the Aryan village community, we see that one of its most distinctive features is represented by an axiom well known to modern lawyers-joint in food, worship, and estate. This formula is most interesting, first in its character of a survival;

a English Commonvealth, vol.i. p. 59.

b Spencer's Principles of Sociology, vol. i. p. 68. Cf. Tylor's Anthropology, p. 420. 
secondly, from its giving the starting point to all researches into the history of property and its attendant rights. Although it will take us a little far afield, it is necessary for one moment to glance at the evidence of the existence of the curious features of this famous formula.

1. Joint in Food.-The details of the system of common rights of food are most interesting, and Mr. Morgan, in his Houses and House Life of the American Aborigines, has worked out this subject to some length. All the Indian tribes, he says, who hunt upon the plains observe the custom of making common stock of the capture (p. 69). In Australia the same fact is to be observed, Messrs. Fison and Howitt noting that there was "a common right to food in the family." "So among the Kaffirs of Natal "food is regarded as common property." b Similar evidence is to be obtained from other parts of the savage world. ${ }^{c}$ Among Aryan people the continuity of the custom is proved by the customs of India, Sir John Phear telling us that it is the universal habit in Bengal for the members of a family to live joint. ${ }^{d}$ In Russia, even at the threshold of disintegration, we see the South Slavonian house-communities absorbing the profits earned by members of the family at a distance from their home, into the family chest. ${ }^{e}$ Among the tribal communities of Wales the principle was observed to exist by Giraldus Cambrensis, who says "none of this nation ever begs, for the houses of all are common to all" (cap. x.). And finally I have ventured to trace the survival of the same archaic notions of joint living in many of our own local and manorial customs, in the gild constitution of the middle ages, in the leet-ales, clerk-ales, bid-ales, brideales, and other rural feasts.' Mr. Elton, too, has added very significantly that the modern house-warming following the change of residence is a survival of joint living, based upon the archaic theory of blood-relationship."

2. Joint in Worship.-The primitive group of kinsmen is knit together under the protection of the family deity, and its integrity is sacred against all comers. Thus among the Samoans the house is built by directions of the family god. It

a Kamilaroi and Kurnai, p. 207. B Shooter's Kaffirs of Natal, p. 226.

- A good instance may be mentioned among the Andaman Islanders, see Journ. Anthropological Inst. xii. $328,349$.

a The Aryan Village in India and Ceylon, p. 76 ; Mr. J. D. Mayne in his Hindu Law and Usage, p. 188 , sets forth the connection of joint-living with the origin of property very plainly.

- Maine's Early Law and Custom, p. 252. Cf. Wallace's Russia, i. 135.

I See Folk-Lore Relics of Early Village Life, p. 157.

g Origins of English History, p. 404. 
could never, under any circumstances, pass from the family.a Among the New Zealanders, again, houses are accounted sacred to the use of the persons for whom they are built, and rarely after a battle, when every savage enormity has been perpetrated, are the houses of the murdered proprietors made use of by the rulers. $^{\mathrm{b}}$

This is a widely-spread and interesting belief and custom; and just to carry on the thread from savage people to our own land, it is perhaps sufficient to ask the significant question-was it not this self-same phase of belief which dictated to the English conquerors of Britain the desire to destroy and leave the stone buildings of their Roman predecessors, and to live in their own "wattle and daub" ? " There is some evidence of this interesting fact to be obtained from folk-lore; but without detailing that here, we may note the curious passage from Beda, who says that King Ethelbert of Kent would not receive Augustine and his companions in any house lest, according to ancient superstition, magical arts might be imposed upon him. ${ }^{d}$ If this be compared with savage beliefs, it is clear that our Anglo-Saxon ancestors had a wholesome fear of the malignity of the house-gods of their enemies, and there is very ample evidence in the survivals preserved by folk-lore to restore, in outline, at all events, the main features of the domestic hearth-religion of the Celtic and Anglo-Saxon races of Britain. ${ }^{e}$ This domestic worship sees the family united by the sacred bond of worshipping at the family altar, the ancestral family deity.

3. Joint in Estate.-If the rights of food are held in common, and the sacred rites of religion bind all together in a common home, there is not much room for the individual acquisition of property; and in fact we see in the plainest fashion that the right of property dwelt in the collective group. When this archaic group settled down into agriculture the same collective idea of property is observable. As the products of hunting were held in common, so are the products of agriculture, and so in course of time are the lands which produce such products. Thus we arrive by very well marked stages of development at the village composed of separate families, each of which is settled within its own

a Pritchard's Polynesian Reminiscences, p. 109.

b Polack's Manners and Customs of the New Zealanders, vol. i. pp. 204, 216.

c Mr. Wright suggests that frequently the Anglo-Saxons occupied the Roman Villa, but I see little evidence of this, and the best authorities are against it.

d Beda, Eccl. Hist. Bk. I. chap. xxv.

e The exact evidence of this I have tried to trace out in my Folk-lore Relics of Early Village Lije, and ef. Elton's Origins of English History, pp. 210 et seq. 
homestead, and in virtue of such homestead, partaking in common with other similarly situated families, of rights in the surrounding village-lands, from the cultivation of which the whole group subsist. Now in this village group legal rights and status exist, not as between individual and individual, but as between family and family.

It is to this ancient family, joint in food, worship, and estate, that we must now turn our attention. It has gained its rights and its collectiveness (if the word is admissible) by the growing powers of the domestic religion which invested the homestead in the family-inalienably in the family. The members of the family had severally no rights within it. Their provisions, their clothing materials, their industrial utensils, their lands, belonged to the collective group. So long as this group of kinsmen kept together each member would share in the property accumulated in the homestead, would partake of its rights and privileges, would seek its protection and incur its responsibilities-the question of succession would in fact never occur. Only when such a homestead died out through want of male members would the question of its relationship to the village generally be raised; and in the social disgrace and religious misfortune with which such a catastrophe was regarded in ancient Rome and in modern India we can discover the principal cause of the various methods adopted in early society to prevent this state of things. ${ }^{\text {. }}$

Now it will be evident that a time will come when this group of kinsmen, so strictly bound together in the homestead, must split up, the increase of its members under favourable circumstances of existence becoming too great for its welfare or its capacity to exist. As a matter of fact one cannot of course imagine an indigenous group which has never undergone this splitting-up process. The picture of such a group as I have just ventured to depict represents a family perfect and intact it is true; but the right to so represent this is due to the fact that the archaic family does not suffer from the process of splitting-up. It gets rid of its departing members or section and it then closes in again to resume its old course, the new section also closing in and becoming in its turn a perfectly intact family group. It is not at this stage that the real question of succession would arise, and this can be best shown by a few examples of the formation of new groups.

A quotation given in Laveleye's Primitive Property (p. 7), from M. de Play, well illustrates the process of archaic disintegration. "Among the nomads (of

"This is fully discussed in Mr. J. D. Mayne's Hindu Law and Usage. 
Russia) the direct descendants of one father generally remain grouped together; they live under the absolute authority of the head of the family in a system of community. We may say that nothing is the subject of separate ownership, except their clothing and weapons. When the increase of a family no longer admits of all its members remaining united, the head of the family directs an amicable separation, and determines the portion of the common possessions that should be given to the branch which is separating from the stem. On the other hand the community often holds together after the death of the head of the family." The same system is observable among the settled tribes who live under the organization known as the mir. "When the mother village became overcrowded," says M. Laveleye," "a group was detached which advanced towards the east into the profound forest and vast steppes, where they found themselves face to face with the nomadic hunting tribes," and where, as M. Laveleye goes on to say, the strict organization of the mir enabled them to combine and conquer. In India the same thing occurred, according to the evidence of Mr. Tupper. ${ }^{\mathrm{b}}$

That this self-same kind of process must have gone on in England during the time of the Anglo-Saxon settlement requires little or no proof. It is discoverable in the curious distribution of clan names in our names of places, which " accords with the supposition that the Saxon rule has gradually extended over the western and central districts by the cadets of families already settled in the island, and not by fresh immigrants arriving from abroad." " Mr. Kemble has pictured the process going on, ${ }^{\mathrm{d}}$ and Mr. Seebohm in his English Village Community, p. 171, has rescued from a MS. in the British Museum a portion of one of Alfred's treatises which allows us to obtain a vivid little glimpse of the possible growth of new communities. So long as there was enough land, daughter-communities would be continually sent forth to relieve the congestion from over-population, and no question of succession would yet have arisen. It will be seen hereafter that this phenomenon of history has left its mark upon the history of succession.

But there was another method of relieving the congestion of society arising from the pressure of population, and it will be necessary to notice this, for it, too, has, I venture to think, left its trace upon the laws of succession.

a Primitive Property, p. 34, and consult Wallace's Russia, vol. i. p. 255.

b Punjáb Customary Jaw, vol. ii. p. 40, and ef. Magne's Hindu Law and Usage, p. 180; Lewin's Wild Tribes of S. E. India, p. 257.

c Taylor's Words and Places, 6th edit: p. 86, et seq.

d Saxons in England, vol. i. pp. 65, 70. 
M. Kolben speaking of the Hottentots says, "When persons of either sex become superannuated or in short unable to perform the least office for themselves, they are then, by the consent of the kraal, placed in a solitary hut, at a considerable distance, with a small stock of provisions within their reach; where they are left to die of hunger or be devoured by the wild beasts." ${ }_{a}$ This really points to the death of the aged when the means of subsistence falls short, that is when the property of the group ceases to support. But the curious point to note is that this barbaric custom has close parallels within the ken of our own archaic history.

In the first place it certainly can be traced in a part of the history of the Valhalla of the early races of Europe. Mr. Duchaillu has noticed that "a few miles from Karlshaum there is a beautiful spot called Valhalla made of gigantic boulders piled one upon another, which form in one part a grotto. This was in heathen times an ättestupa, that is a place from which the people when old and infirm used to throw themselves, it being considered shameful to die in bed or of old age." "And this I connect with "an old countrie story" which Aubrey mentions under the title of "the holy mawle." This was a hammer which "(they fancy) hung behind the Church dore, which when the father was seaventie the sonne might fetch, to knock his father in the head, as effote, and of no more use."

It will be readily admitted that the English "countrie story" is a very archaic form of this savage practice of killing the aged and infirm. But the important part of this subject for our purpose is that this country custom discovered by Aubrey is connected by unquestionable evidence with the descent of property. In the Gentleman's Magazine for 1850 (Pt. i. pp. 250-252) Mr. W. J. Thoms gave an explanation of the holy mawle, identifying it with the hammer of Thor, and in the course of his most interesting researches he gives some curious facts which will be worth while noting.

Mr. Wright, in his volume of Latin stories published by the Percy Society, prints one story in which an old man surrenders all his property to the husband of his daughter. It is important to note in passing that this surrender can be archaically accounted for by the practice of appointing a daughter to bring an heir. But in the medieval Latin story the father gets ill-treated and at last

a Mavor's Collection of Voyages, iv. 41.

b Land of the Midnight Sun, ii. 438.

- Remains of Gentilisme and Judaisme (Folk-lore Society), p. 19.

d Vol. viii. 29.

VOL. L. 
driven out of the hotise. He gets taken back again, however, and at the point of death, as it is graphically stated, "antequam totaliter expiraret, ad cistam currentes nihil invenerunt nisi malleum, in quo Anglice scriptum erat
Wyht suyle a betel be he smyten,
That al the werld hyt mote wyten,
That gyfht his sone al his thing,
And goht hym self a beggyn.

In this Latin story, softened down to meet the tastes of medieval storytelling, we see traces of Aubrey's " holy mawle" custom in operation, and it is a singular coincidence that in several of the cities of Silesia and Saxony there hangs at the city gate a mallet with this inscription :

Wer den kindern gibt das Brod

Und selber dabei leidet Noth

Den schlagt mit dieser keule todt.

which may be Englished thus :

Who to his children gives his bread

And thereby himself suffers need,

With this mallet strike him dead.

Of course, in these variants we have lost the original significance which is preserved in Aubrey's record of the custom in England. But the German scholar Nork has proved that " the English construction must necessarily, as the earlier, precede the German," and Dr. Guest supplies some information, which to my mind helps to confirm this opinion. We not unfrequently, he says, find an axe traced on the slabs used in the construction of ancient sepulchral chambers; and in a certain Breton tomb (Arch. xxv. 232) the axe is sculptured in relief on the underside of the covering slab, immediately above where the body lay; and there are many inscriptions on Gaulish tombs erected during the first three centuries which contain the formula "sub ascia." " Is not this axe to be identified with the "holy mawle" of Aubrey, thus bringing the whole group of customs into close connection with that ancient practice of killing the aged and infirm rather than break up the family?

- Origines Celticae, ii. 85. 
Not only does this curious survival help us to understand the permanence of archaic ideas, but it seems to be closely connected with another set of customs, which show the setting aside of the father when old age comes on; and thus we get a kind of development from the actual killing of the father. ${ }^{a}$ Some examples of this will be interesting and instructive.

By the custom of the country of Spiti, the father retires from the headship of the family when his eldest son is of full age, and has taken unto himself a wife . . . on each estate there is a kind of dower-house with a plot of land attached, to which the father in these cases retires. When installed there he is called the Káng Chumpa (small-house man). ${ }^{b}$ The Scandinavian parallel to this has been described by Mr. Du Chaillu, in a passage which I think contains portions of the old formula and rights attending the ceremony. "On a visit to Husum, an important event took place, when, according to immemorial custom, the farm was to come into the possession of the eldest son. The dinner being ready, all the members of the family came in and seated themselves around the board, the father taking, as is customary, the head of the table. All at once, Roar, who was not seated, came to his father and said: 'Father, you are getting old; let me take your place.' 'Oh no, my son,' was the answer, ' $\mathrm{I}$ am not too old to work; it is not yet time: wait awhile.' Then with an entreating lnok Roar said, 'Oh, father, all your children and myself are often sorry to see you look so tired when the day's labour is over: the work of the farm is too much for you ; it is time for you to rest and do nothing. Rest in your old age. Oh, let me take your place at the head of the table.' All the faces were now extremely sober, and tears were seen in many eyes. 'Not yet, my son.' ' Oh yes, father.' Then said the whole family: 'Now it is time for you to rest.' He rose, and Roar took his place and was then the master. His father, henceforth, would have nothing to do, was to live in a comfortable house, and to receive yearly a stipulated amount of grain or flour, potatoes, milk, cheese, butter, meat, \&c." " In this curious narrative it is important to note how the formula adopted for the carrying out of the ceremony leads us to suppose that the occasion is a very painful and trying one to the family, and it suggests itself to my mind that in the old formula we have traces of the still older customs of the Valhalla. Similar customs existed in

a A passage in Polack's New Zealanders (i. p. 27) suggests that as soon as the son was born, he, " boasting of an additional branch to the ancestral tree," is superior to his progenitor.

b Tupper's Punjáb Customary Law, ii. p. 188.

- Du Chaillu's Land of the Midnight Sun, i. p. 393. 


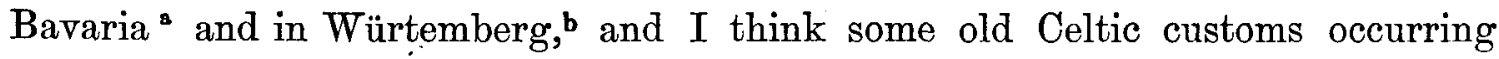
in Kinross, Ireland, and in Cornwall are to be referred to the same origin. ${ }^{\circ}$

From the customs we have just examined, existing among uncivilized people and in our own country, we have the proposition before us that before the question of succession to property either moveable or immoveable could have arisen the process of migration to new settlements must have come permanently to a close, and the practice of killing the aged and infirm must have ceased. When society had reached this stage, there arose for the first time what must have been a most momentous problem in primitive politics--how is the homestead to be preserved with all the sacred traditions of the ancestral hearthworship clustering around it, and to whom was to be intrusted the sacred duty of carrying on the family and performing the religious duties to the deceased father or head?

The first answer given to this question was undoubtedly that the homestead must not be divided, never mind by what social risks or impoverishments such a course would be attended. How sturdily the question has been fought, and how largely the influence of a priestly religion has been brought to bear against this archaic position of absolute impartibility may be ascertained so far as India at all events is concerned by a study of Mr. J. D. Mayne's Hindu Law and Usage, where it is laid down that originally partition of property was entirely unknown (p. 191) until the influence of Brahminism was brought to bear upon the family, and which " has only been exerted for the purpose of breaking it up" (p. 5). ${ }^{\text {" }}$

It will be unnecessary to detail the history of the influences of the Christian priesthood on the law of property in Europe, for it is well known that its effect has been parallel to that of Brahminism in India. ${ }^{e}$ But it is worth while pointing out how in face of this influence the old rules of society have survived in the many significant facts which have long affected the laws of succession in England. They are curious and deserve some investigation, and the result will prove, if I

a See Cobden Club Essays-Primogeniture.

- Tupper's Punjáb Customary Law, ii. 188.

c I will merely refer my readers to Ure's Agriculture of Kinross, 997, p. 57; and cf. Mason's Statistical Account of Ireland, vol. ii. p. 209, and Carew's Cornwall, p. 38.

d But the idea spreads far beyond India. In Burmah, says Colonel Phayre, "it is considered that land cannot be alienated from the family it belongs to: there appears to be almost a religious objection to parting finally with it"-Ethnological Society, vi. 228; and one of our greatest difficulties in the Transvaal arose from the native idea that land was not saleable. See Correspondence, Parliamentary Paper, 1885 (c. 4588 ), p. 45.

e This has been touched upon in Essays in Anglo-Saxon Law, p. 73. 
mistake not, that in this branch of our local law we have traces of that older Aryan society which believed in the absolute impartibility of the homestead and the social unit within it.

The impartible nature of property can be shown to have existed in our own land by some curious examples of the long survival of joint-ownership, itself a development from the old family rights. Only lately M. Fustel de Coulanges, in his Recherches sur quelques problèmes d'histoire has had occasion to point out that the slight glimpses of the German law of inheritance afforded by Tacitus indicate that land was the joint property of the family, and that it was indivisible." "When brothers share their patrimony" is the significant formula of the Welsh laws." In Ireland "sometimes the co-heirs did not divide the land but continued to occupy the land in common." In Domesday Book there are some few instances of males holding in co-parceny, or as it is there expressed in paracio. It is impossible here to go into the curious evidence which Domesday supplies of group-holding, but in the cases where the township was held as a joint property by a small body, Sir Francis Palgrave can only suppose that inheritances when divided were partible amongst the male heirs. ${ }^{d}$ But joint-property held by the township community is a direct descendant from the joint-property of the village community. In Scotland I have succeeded in discovering several instances of joint tenancies, where the property has remained impartible down to modern times, though, of course, at the present time it possesses more of the characterestics of modern legal holdings than of the archaic family holding. ${ }^{\text {. }}$

In Scotland, too, there is another interesting fact which enables us to grasp how strong was the feeling against the splitting up of the homestead. It is that some estates are to be seen, as for instance in North Uist, ${ }^{\mathrm{g}}$ and in the Island of Harris in 1795, held in a kind of joint ownership by the chieftain and his descendants. Of old, says Sir John Sinclair, the chieftains planted their younger sons about them upon their own property and gave them portions of

a Cf. also Hampson's Origines Patriciae, p. 343; and in that unsatisfactory work, Ross's Early History of Landholding among the Germans, ample evidence is collected from the laws proving the original indivisibility of family property.

b See Leges Walliae, quoted by Mr. Elton, Origins of English History, p. 137.

c See Sullivan's Introd. to O'Curry's Lectures, i. p. 182. Also Brehon Law Tracts, vol. iv. p. cv.

d Hist. Eng. Com. i. p. $66 . \quad$ e See my paper in Archaeologia, vol. xlvi. pp. 403-422.

f I have duly discussed the archaic nature of these joint tenancies in my address to the Glasgow Archaeological Society, November 1884.

g See Sinclair's Stat. Acc. of Scotland, vol. xiii. 310. 
land for small yearly rents which were continued with their descendants from one generation to another. Under such a system as this the old chief homestead was preserved and the clan became settled in the lands around forming an integral property which in relation to the chief homestead had not been split up and divided. Each little section was doubtless subject to its own rules of descent according to the modern laws, but in its origin the formation of the estate was archaic, and it answered at the time the question we are now discussing, namely, what was to be done when migration to new settlements was permanently stopped.

In English manorial customs we meet with evidence which is illustrative of this portion of our inquiry, and which is a sort of counterpart, under other influences, to the Scottish customs just noticed. In Lancashire and some parts of Cumberland the lord of the manor is compelled to grant a piece of ground for a house and garden to a newly-married tenant. ${ }^{2}$ Clearly as regards the so-called tenant-lands, there could be no question of succession. But the struggle of the archaic family to hold its own in England is still to be traced in English law. ${ }^{b}$

I think the impartible nature of property is shown in the later history of the guild and the freedoms of municipal boroughs. Much has been written upon the origin of the guild; but one thing stands out very clearly, namely, that at one time it was a band of relations holding property in common, that is, the property was impartible, and succession took place by birth within the guild organization. This was the case at Totnes so late as 1260 , and in many other places. When the guild organization gave way before commercial ideas the archaic rules became extinct; but I think the true history of this process may be traced by a comparison between the later influences of locality against the archaic influences of kinship, a comparison which, in the case of early Greek institutions, has been very ably dealt with by Mr. Fison. In the same way succession to municipal freedoms was frequently down to modern days by kinship, the enjoyment of the common property being conveyed by this tie.

The full force and significance of this objection to the partition of ancestral property in early society has not, I think, been sufficiently taken into account when endeavouring to elucidate points in early law and custom. Certainly $\mathrm{Mr}$. Seebohm has missed the point when he argues that the holders of yard-lands, or bundles of recognised strips of land in the open fields, were villeins, because,

s Hampson's Medii Aivi Kalendarium, i. 289. The same curions custom existed in Scandinavia. See Du Chaillu's Land of the Midnight San, vol. ii. p. 251.

- Essays in Anglo-Saxon Law, p. 72 ; Elton's Tenures of Kent, p. 137; Spence's Court of Chancery, vol. i. 148-149. 
among other characteristics, their holdings were indivisible." "The very possibility," he says, "of this permanent succession, generation after generation, of a single holder to the indivisible bundle of strips called a yard-land or virgate, ... seems to have implied the servile nature of the holding. The lord put in his servant as tenant of the yard-land, and put in a successor when the previous one died. This seems to be the theory of it.". No doubt from Mr. Seebohm's point of view this theory fits in with the rest of his researches; but when we consider that the non-partition of a homestead and holding is the archaic rule, and that it held its own against great forces far down into modern times, the evidence seems to suggest that the villagers of King Ine's time, who were holding their yard-lands from generation to generation, were doing so not in obedience to the lord, but in accordance with a usage which was once sacred in their eyes, and which had still all the traditional reverence of immemorial custom - a usage sanctioned by authority far more powerful than a lord or chieftain in Anglo-Saxon times would have attained. This usage in point of fact takes us back to the "ancestral shares" of the free village community and absolutely identifies Anglo-Saxon custom with the customs of archaic, and hence unromanized, society. ' Further, it must be noted that Mr. Seebohm adopts the language of the modern lawyer when he speaks of a "single holder" of the indivisible bundle of strips. The single holder has at his back the family group occupying the homestead, from which he simply stands forth as representative. And the question as to how this group was to subsist when it became too large for its holding was answered in later Saxon times, when daughter-communities had ceased to colonize, by a process which can be shown to be perfectly archaic. This was the large influx of men into towns when commerce began to demand such recruits, and whom archaic law refused to recognise (as "landless" men) unless they put themselves under the legal protection of some lord. Thus we find

a English Village Community, pp. 176, 419 .

b It is curious to note that this idea seems to have occurred to Mr. Seebohm himself, for at p. 77 of his work he says, "They (the villani) possessed all the unity and indivisibility of an entailed estate and were sometimes known apparently for generations by the family name of the holders. But the reason underlying all this regular devolution was not the preservation of the family of the tenant but of the services due from the said land to the lord of the manor."

c Mr. Seebohm admits this when dealing with the Irish tribes, see p. 217. But indeed it is shown by many valuable examples. Grimm, Rechtsalterthümer, p. 539, says, the possession of a house was the source of all other rights; and in English law municipal rights are in many places attached to the house. 
that to many of the Domesday manors are said to belong so many burgesses"huic manerio pertinent 6 burgenses in Crichelade" are the words with reference to Aldeborne in Wilts. But these burgesses retained in the towns the duties and rights of their own family homesteads, just as in Russia members of the village community frequently go into the towns to work but still retain all their old archaic relations with the mir.

Having thus far dwelt upon the obstacles which barred partition of family property we will next consider the state of things when partition began to be recognized. It will be found that several legal limitations were enforced, and some of these may be mentioned.

In India, where the objection to the partition of property exists in full force to the present day -in fact where property is considered to be joint unless proved to the contrary - one of the limitations to partition is with reference to the housemother. "There seems," says Mr. J. D. Mayne," " to be no doubt that originally the right of brothers to divide the family estate was deferred till after the death of the mother. . . . According to the Thesawaleme this is actually the rule. When the father dies leaving children, the mother takes all the property and gives the daughters their dowry but the sons may not demand anything as long as she lives." The Thesawaleme here alluded to is a description of the customs of the Tamil inhabitants of Jaffa, on the island of Ceylon, and Mr. Mayne goes on to give corroborative evidence from Naroda and other Hindu law writers. I think some rules of descent in English manors may be interpreted by the same archaic standard. In Somerset, the well known case of Taunton Deane, the widow succeeds " as next heir unto her husband." At Braunston in Northamptonshire the widow succeeds upon the performance of a particular custom; ${ }^{\circ}$ at Orleton in Herefordshire ; at Southwell in Nottinghamshire; $;^{\mathrm{e}}$ at Stockwood in Dorset; ${ }^{\mathrm{f}}$ and in other places the widow succeeds for her life, the property then going to the heirs of the husband. Now this in archaic law is simply a deferring of the partition until the death of the widow, a reading of the evidence which is confirmed by the fact that the provision for the chastity of the widow obtains in India as well as in England. Mr. Mayne says that the archaic explanation of this is that originally the widow succeeded so that she might raise up issue for her husband and that of course the male relations would have a strong interest in inducing a widow to

a Hindu Law and Usage, p. 194. Compare the custom of the Andaman Islanders recorded in Anthropological Institute, vol. xii. p. 141.

b Shillibeer's Customs of Taunton Deane, p. 42.

- Hazlitt's Tenures of Land, p. 37.

d Ibid. 236.

e Ibid. 289.

t Ibid. 298. 
refrain from exercising her right and she would have a specially strong interest in availing herself of it; the obvious compromise to this being to allow her to succeed at once to a life estate in the property provided she waived the privilege of producing a new owner. ${ }^{\mathrm{a}}$

In these cases the absolute impartibility of the property, that is of the family homestead, is the underlying basis of archaic thought which has given rise in various ways to customs still to be found extant in all branches of the IndoEuropean race. In the oldest days it was a question of migration to new settlements, or the death of the aged and infirm, and of infants, which decided the limits which a family community put upon itself for the support of all its members and the keeping together of the homestead. And even when commercial ideas had so far got the better of traditional ideas, that family properties became alienable, though not necessarily partible, there existed a law which again illustrates the strong force which archaic custom has upon even the most progressive of societies. This is known as the right of pre-emption, that is, the right of any member of a family to re-purchase property, which, having once belonged to the family, had, owing to some circumstance or other been sold or otherwise parted with; for in the words of Mr. J. D. Mayne, "as long as the land held by a family was only proportioned out by the community for their use, it is evident they could not dispose of it to a stranger without the consent of the general body, ${ }^{\text {, }}$ and this restriction was extended to the right known as preemption, when the land became saleable. This right exists all over the Punjáb, and in many other places, ${ }^{\mathrm{d}}$ but it will suffice if I point out its survival among English customs. It is mentioned in express terms in Ine's and Alfred's Laws, from which I will quote the following extracts, as they are little known in connection with the important subject they illustrate.

In Ine's Laws (c. 38) it is provided, "If a ceorl and his wife have a child together, and the ceorl dies, let the mother have the child and feed it; let them give her .... shillings for support-a cow in summer, an ox in winter. Let the kin hold the homestead until it (the child) be grown up."

In Alfred's Laws ( $\$ 41$ ), it recites that "if a man have land, and his kin left it him, then we declare that he must not sell it out of his kindred if there be writing or witness that the man forbade who first acquired it, and those who granted it to him, that he might not."

" Mayne's Hindu Law, p. 447.

b Hindu Law and Usage, p. 187.

c Tupper's Punjáb Customary Lau, vol. ii. p. 36.

'For the Scandinavian evidence, see Du Chaillu's Land of the Midnight S'un, ii. 290.

vol. $\mathrm{L}$.

$2 \mathrm{E}$ 
A charter of 804 (Cod. Dip. clxxxvi.) is an example of the grants which subsequently were embodied in this law. Ethelric comes before the synodical council "cum libris et ruris . . . . . . quod propinqui mei tradiderunt mihi et donaverunt." A charter of Offa's, of still earlier date (776), contains a limitation to the family in terms "post se suae propinquitatis homini cui ipse vo[luerit]" (Cod. Dip. cxxxvii).

In Domesday the right of pre-emption is expressly mentioned in the record relating to Lincoln, and there are other instances of it. Nottingham, Preston, Salford, Winchester, Fordwich, are among the boroughs which I have been able to identify as possessing this archaic provision relating to property, and it is found frequently in manorial law. ${ }^{2}$ In Ireland the custom is shown to exist most curiously, as the subjoined note will illustrate. ${ }^{\mathrm{b}}$

These few examples have illustrated the impartible nature of the archaic homestead and its attached rights of property, by showing what took place at the time when the question of partition was first presented to the members of the primitive community. And we have established, if my reading of the evidence is correct, that the self-same class of action which arose in India under these conditions exists, or has existed, in England. In India this action and its consequent legal notions are demonstrably archaic, and they live in a society where primitive politics is the governing force; and from hence we may argue that the parallel customs in England originated in the same condition of things, and hence illustrate the same phase of primitive life. We have now to apply ourselves to the final portion of our inquiry-what relation do these archaic notions of property, isolated and peculiar as they stand in English law, bear to the more fully recognised customs of succession-primogeniture and junior-right?

Both primogeniture and junior-right are known to the most archaic types of society which the modern inquirer is able to discover; but they are known, not as

a Elton's Origins of English History, p. 404.

- In Hardeman's Ancient Irish Deeds and Writings chiefly relating to Landed Property (Dublin, 1826, p. 54), it is stated that "the consent of the entire tribe or family was necessary before an individual could alienate any part of the Inheritance. Deed No. xix. is a mortgage of lands belonging to Donald MacShane to Donald O'Slattery. The conditions between Donald O'Slattery and Donald MacShane are that it shall not be in the power of any person to redeem that land from Donald O'Slattery, except Donald MacShane himself, his son or grandson. The green of Killeen is the place charged with his mortgage as is attested by Donald [

] i.e. Sheeda and his children Finian and MacCon, and Mera, daughter of Bryan in like manner, and the children of Commeadha MacLoghlan, and many others of the race, who have given their permission and consent at both sides, A.D. 1502, this covenant has been entered into between them." 
customs governing the right of succession to property, but as governing the right of succession to chiefship. This is an important distinction. Long before the question of the partition of property arose, there was need of some law of succession to the headship of the family, or the chiefship of the clan. ${ }^{a}$ It was this head, or chief, who performed the funeral rites and the religious ceremonies at the sacred hearth to the manes of the deceased chief and his ancestors, and that this duty was a vastly important one in all branches of the Aryan family there is plenty of evidence to prove.

In India, where the house-religion and house-altar at the domestic hearth have not been disturbed, the question of succession to the headship of a family is almost inextricably mixed up with the question as to who should succeed to the right of offering funeral oblations to the deceased chief. And Mr. Mayne significantly quotes from Dr. Mayr, that " in later times when partition was resorted to, it became necessary to define who should offer the funeral cake, and naturally this duty fell upon those who took the inheritance." b

This, then, shows us the connection between succession to chiefship, and succession to property. It comes about at the stage in the history of society when property has lost its ancestral nature and has become partible.

The first instinct when once property became parrible was to divide it amongst all the sons, corresponding to the more archaic practice of dividing the common property equally when the family was separating off to form new communities in different homesteads. And so when we come to consider where it is that this equal division takes place, we find it to exist in those places which retain most strongly the relics of early tribal organisation as distinct from village organisation. This is an important feature. But there also exists evidence to show that this partition was originally most fully and completely guarded by a long process. In Ireland, for instance, "the division of property took place in this way; each son was entitled to an equal share of the cattle and land, but not of the houses and offices, the pots, the brewing vats, and other vessels and implements, which went to the elder brother, together with the houses and offices. But in consideration of this special inheritance he was bound to accept the responsibility of entertaining the retinue of the king, a bishop, or a Sai. He was the stem of the family, and until his brothers became of age was responsible before the law for them, and the assertor of their rights; the guardian of his sisters and other members of the family; and plaintiff and defendant in all suits of law. During the first year of their co-occupancy, a temporary staking

a Cf. Mayne's Hindu Law and Usage, p. 435.

b Ibid. 
of the several shares of the land took place; and in the second, an exchange of lots, in order that each should know the quality and capabilities of the land of the other. In the third year the land was measured by poles and ropes to determine boundaries. In the fourth year the boundaries were conformed so as to bar litigation thereafter, and each brother gave security to maintain his fences. The Ail or boundary was begun to be made around it at the end of the fifth year, and should be finished within the tenth year, with the exception of a comb or capping of blackthorn, which need not be finished before the end of that year. One month after the completion of the fence the division of the land and establishment of the boundaries were legally proclaimed." "The woods, bogs, and waste continued common." a

The position of the elder brother in this interesting record is the position which is assigned in India to the son who takes upon himself the religious duties to the deceased ancestor; and it is this position which decides alike the origin of both primogeniture and junior-right.

Reeve, in his History of English Law (i. 76) says that "as low down as the reign of Henry I. the right of primogeniture was so feeble that if there was more than one son, the succession was divided, and the eldest son took only the primum patris feodum: the rest being left to the younger son or sons." Mr. Elton has pointed out that in gavelkind as in junior-right, it was customary to " let all the sons divide the heritage equally . . . but the hearth-place shall belong to the youngest son . . . and as far as forty feet round the hearth-place." b Thus the oldest forms of both primogeniture and junior-right lead us back to archaic notions of property, namely, that the homestead is sacred and impartible, that so long as the family remains together the possessions attaching to the homestead are also impartible, and that so soon as partition is admissible, equal division takes place, the homestead, however, going intact to a specially selected heir. "Property," says Mayne in relation to Hindu law, "which is in its nature impartible, can of course only descend to one of the issue, which that one is to be will depend upon the custom of the family." "

This factor in Hindu law enables us to ask, with reference to English law, is it archaic family custom which in one place allows the eldest son to succeed to the headship of the family, and in another place the youngest? ${ }^{d}$ It is at this

a Sullivan's Introduction to O'Curry's Lectures, vol. i. pp. clxxx-clxxxii.

b Origins of English History, p. 190. The portions omitted from this quotation do not affect my argument.

c Hindu Law and Usage, 462.

a Lewin in his Wild Races of $S$. $\boldsymbol{E}$. India gives an instance where eldest and youngest inherited to the exclusion of others, p. 280 . 
point that it becomes necessary to note that the family or group we are now dealing with has passed through the stages where kinship is only reckoned through females and has become a kindred reckoning its rights of membership through male descent. Turning to an example of such a kindred we may be guided by the curious evidence afforded by Kafir law, as to the answer to be given to our question: for it is the Kafir practice for the chief to have several wives, and when in old age he has a child by his favourite young wife, it is this child, the son of his youngest wife, and hence probably his youngest son, who succeeds to the chieftainship. ${ }^{n}$ On the other hand, in India, where primogeniture is the general rule, the question as to who is the eldest son does not depend upon the seniority of the mother, but on priority of birth - the eldest son is the son who was born first, not the first-born son of a senior wife. ${ }^{b}$ But the comparatively late form of individual succession in India, aided as it has been by English legal ideas, cannot shut out the much earlier rule that the position of the mother materially affects the laws of succession, even after kinship has ceased to be reckoned through females. ${ }^{\circ}$ It is therefore important to note that mother-right has by no means disappeared from the customs of rural England. In the fishing town of Staithnes, in Yorkshire, the children are all called by their mother's names," in some parts of Ireland, ${ }^{e}$ in Wales, ${ }^{\mathrm{f}}$ and in Scotland ${ }^{\mathrm{s}}$ the same practice obtains. If these examples be considered, together with all that Mr. McLennan has advanced, as to the wide-spread influence of the system of female kinship, we may well suggest that the fact of mother-right not even now being dead amongst us, shews it must have exercised considerable influence upon family custom within historical times.

If that influence tended in any way to sanction the practice of junior-right, or to familiarize men with the idea that the succession of the youngest was an admissible custom in certain circumstances, there was one other great event in the history of the family settlement in England which threw all its weight into the scale in favour of establishing such conditions as would make the recognition of the rights of the youngest inevitable in certain districts. This was the nature

a Maclean's Kafir Laws and Customs, p. 26.

b Mayne's Hindu Law, p. 462.

c In Polack's New Zealanders it is related how a certain chief, proposing to bring home a new wife, the old wife objected until the chief promised "before her relations that her children only should have the inheritance," vol. i. p. 50.

a Notes and Queries. [I have lost this reference, but am certain of the fact].

e Mason's Statistical Account of Ireland, i. 48.

' Pennant's Tour in Wales, p. 406.

s Burt's Letters from the Highlands, i. 63. 
of the settlement itself. Mr. Isaac Taylor in his Words and Places has an instructive table, showing from an arrangement of place-names what proportion of "original settlements" to "filial colonies" each county possesses. It is found that the names of the former class-original settlements-are chiefly to be found in the south-eastern districts of the island, where the earliest Teutonic settlements were formed, namely, Kent, Sussex, Middlesex, Essex, Norfolk, Suffolk, Beds, Hants, and the adjacent counties, and that these original Teutonic settlements gradually diminish in frequency as we proceed towards the northern and western counties, until in the semi-Celtic districts of Derbyshire, Devonshire, and Lancashire, they are wholly, or almost wholly, wanting. Now this instructive piece of history shows which counties, possessing original settlements, sent daughter-communities to settle in the more distant lands; and it is exactly in those same counties (where we find that in early Saxon times the village communities split up, and sent sections to form village communities elsewhere) that we find also the prevalence of the custom of junior-right, namely, Kent (the whole county), Sussex (140 manors), Middlesex (16 manors), Essex (14 manors), Norfolk (12 manors), while to the north of a line drawn between the Humber and Mersey the usage appears to have been unknown. Can we resist the conclusion, therefore, that the communities in settlement in the districts of Kent, Sussex, Middlesex, Essex, and Norfolk sent forth their eldest members to form new settlements in the yet unconquered country, leaving the youngest sons to take up the duties of family chief in the villages at home? The old associations of motherright would thus be added to the newer necessities of settlement, and would gradually enforce a custom that youngest sons should inherit the homestead.

We have now gone through the evidence, which shortly, as it is stated here will, I hope, enable us to understand how greatly archaic family custom has affected the laws of succession in England. It is this family custom which gave the initial step towards the creation of certain modern established local rules, the most prominent being primogeniture, or junior-right. And, flowing from this archaic family custom, we have discovered a vast quantity of ideas attached to the conception of property which have in more ways than one affected the growth of laws, or rules, or customs, relating to succession. 